\title{
MLLT1 wt Allele
}

National Cancer Institute

\section{Source}

National Cancer Institute. MLLT1 wt Allele. NCI Thesaurus. Code C53067.

Human MLLT 1 wild-type allele is located in the vicinity of $19 \mathrm{p} 13.3$ and is approximately 70 $\mathrm{kb}$ in length. This allele, which encodes protein ENL, plays a role in the activation of transcription by RNA polymerase II. Mixed-lineage leukemias are associated with the translocation $\mathrm{t}(11 ; 19)(\mathrm{q} 23 ; \mathrm{p} 13.3)$ of the gene with the MLL gene. 